\title{
The physiologic and therapeutic role of Heparin in implantation and placentation
}

Implantation, trophoblast development and placentation are crucial processes in the establishment and development of normal pregnancy. Abnormalities of these processes can lead to pregnancy complications named the great obstetrical syndromes (preeclampsia, intrauterine growth restriction, fetal demise, premature prelabor rupture or membranes, preterm labor, and recurrent pregnancy loss). There is mounting evidence regarding the physiological and therapeutic role of heparins in the establishment of normal gestation and as a modality for treatment and prevention of pregnancy complications. In this review we will summarize the properties and the physiological contribute of heparins to the success of implantation and placentation and normal pregnancy. 
1 The physiologic and therapeutic role of Heparin in implantation and 2 placentation

3 Michela Quaranta ${ }^{1}$, Offer Erez ${ }^{2}$, Salvatore Andrea Mastrolia ${ }^{3}$, Arie Koifman²,

4 Elad Leron², Tamar Eshkoli², Moshe Mazor², Gershon Holcberg ${ }^{2}$

51 Department of Obstetrics and Gynecology, Azienda Ospedaliera

6 Universitaria Integrata, Università degli Studi di Verona, Verona, Italy

$7{ }^{2}$ Obstetrics and Gynecology, Soroka University Medical Center, School of

8 Medicine, Ben Gurion University of the Negev, Beer Sheva, Israel

93 Department of Obstetrics and Gynecology, Azienda Ospedaliero-

10 Universitaria Policlinico di Bari, School of Medicine, University of Bari "Aldo

11 Moro", Bari, Italy

12 Corresponding author

13 Prof Offer Erez

14 Acting Director Maternal Fetal Medicine Unit

15 Department of Obstetrics and Gynecology

16 Soroka University Medical Center

17 Ben Gurion University of the Negev

18 P.O.Box 151

19 Beer Sheva

20 Israel 84101

21 erezof@bgu.ac.il 


\section{1. Introduction}

23 The use of Heparins has increased constantly since their discovery, and this

24 is due to the number of properties and effects shared by these molecules. In 25 addition to their anticoagulant and anti-inflammatory effect, that justifies 26 their employment in the prevention and treatment of pregnancy 27 complications, these molecules have a physiologic role during gestation and 28 especially during implantation and placentation; which is a critical process in 29 the establishment and success of pregnancy ${ }^{1}$. In this review we will present 30 the role of heparins in implantation, placentation, their role in the 31 immunologic balance between the mother and her fetus, as well as 32 discussing the clinical application of these concepts in the improvement of 33 pregnancy outcome in patients with repeated implantation failure (RIF) and 34 recurrent pregnancy loss (RPL). The subject presented herein is brought in a 35 descriptive manner and not as a systematic review in order to allow us to 36 describe in a broad perspective, dedicated also for reader outside of our 37 profession, the rationale for the use of heparins in the above mentioned 38 indications, as a consequence of their biological activity.

\section{The physiological role of heparin}

40 Heparin is one of the oldest drugs currently in widespread clinical use. Its 41 discovery in 1916 predates the establishment of the Food and Drug 42 Administration of the United States, although it did not enter clinical trials 43 until 1935. It was originally isolated from canine liver cells ${ }^{2}$, hence its name

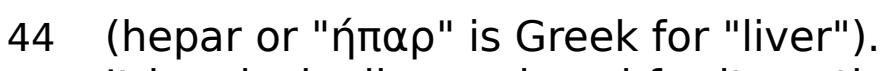

45 It is principally employed for its anticoagulation properties. Moreover, its true 46 physiological role in the body remains uncertain, since blood anticoagulation 47 is achieved mostly by heparan sulfate proteoglycans derived from endothelial 48 cells $^{3}$. Heparin is usually stored within the mast cells secretory granules and 49 released only into the vasculature at sites of tissue injury. It has been 50 proposed that, in addition to its anticoagulant properties heparin may play a 51 role in the defense against invading bacteria and other foreign materials ${ }^{4}$.

52 Heparin is a glycosaminoglycan composed of chains of alternating residues of

53 d-glucosamine and uronic acid. It's major anticoagulant effect is accounted 
54 for a unique pentasaccharide (GlcNAc/NS(6S)-GlcA-GIcNS(3S,6S)-IdoA(2S)-

55 GlcNS(6S) structure that has a high binding affinity sequence to anti56 thrombin III (AT III) ${ }^{5}$; however, in-vitro studies suggest that this structure is 57 present only in about one third of heparin molecules ${ }^{6}$.

58 The interaction between heparin and AT-III mediates the majority of the 59 anticoagulant effect of the former. Their binding produces a conformational 60 change in AT-III (Fig. 1) that accelerates up to 1000 fold $^{7}$ its ability to 61 inactivate the major coagulation factors, including mainly thrombin (factor 62 Ila), factor $\mathrm{Xa}$, and factor $I X \mathrm{X}^{5}$.

63 Heparin increases the inhibitory effect of AT-III on thrombin and Factor Xa 64 activity by distinct mechanisms (Fig. 2). The acceleration of the inhibition of 65 thrombin by AT-III necessitates the binding of this molecule to the heparin 66 polymer proximally to the pentasaccharide units. Heparin has a highly 67 negative charge that is derived from the number of its saccharide units, 68 which contributes to the strong electrostatic interaction of AT-III with 69 thrombin. Thus, heparin's activity against thrombin is size-dependent, and 70 the ternary complex (including thrombin, ATIII and heparin) requires at least 7118 saccharide units for efficient formation and thrombin inactivation ${ }^{8,9}$.

72 In contrast, the effect of heparin on the inhibition of factor Xa by ATIII is 73 dependent on the conformational change of this molecule at the heparin74 binding site; therefore, the size of heparin has no importance in the inhibition 75 of factor Xa by ATIII. This has therapeutic implications and led to the 76 development of a new generation of heparin derived anticoagulants including 77 low molecular weight heparins (LMWH) and fondaparinux. LMWH are 78 obtained as fragments of unfractionated heparin as a result of enzymatic or 79 chemical depolymerization, yielding to molecules of mean weight of $5000 \mathrm{Da}$ 80 (Table 1$)^{10}$ while fondaparinux is a synthetic pentasaccharide based on the 81 heparin antithrombin-binding domain ${ }^{11}$.

82 These medications target the anti-factor Xa activity rather than anti-thrombin 83 (Ila) activity of AT-III, aiming to facilitate a more subtle regulation of 84 coagulation with an improved therapeutic index and less side effects. Indeed, 85 each molecule of fondaparinux binds to one molecule of AT-III at a specific 86 site, and with very high affinity. The binding is rapid, non-covalent, and 
87 reversible. It induces a critical conformational change in AT-III, exposing a 88 loop containing an arginine residue that binds factor $\mathrm{Xa}$. Exposure of the 89 arginine-containing loop greatly increases the affinity of AT-III for factor Xa, 90 potentiating the natural inhibitory effect of AT-III against factor Xa by a factor 91 of approximately $300^{8,9}$.

92 3. The role of heparins in implantation and placentation $93 \quad 3.1$ What are the stages of implantation and placentation?

94 Implantation, a critical step for the establishment of pregnancy, requires a 95 complex molecular and cellular events resulting in uterine growth and 96 differentiation, blastocyst adhesion, invasion, and placental formation.

97 Successful implantation necessitates a receptive endometrium, a normal and 98 functional embryo at the blastocyst stage, and a synchronized dialogue 99 between the mother and the developing embryo ${ }^{12}$. In addition to the well100 characterized role of sex steroids, the complexity of blastocyst implantation 101 and placentation is exemplified by the role played by a number of cytokines 102 and growth factors in these processes. Indeed, the process of implantation is 103 orchestrated by hormones like sex steroids, and hCG; growth factors such as 104 TGF-B, HB-EGF, IGF-1; cytokines as Leukemia Inhibitory Factor, Interleukin-6 105 and Interleukin -11; adhesion molecules including L-selectin and E-cadherin 106 ,the extracellular matrix (ECM) proteins, and prostaglandins ${ }^{12}$.

107 Embryonic implantation is initiated by the recognition and adhesion between 108 the blastocyst surface and the uterine endometrial epithelium. Adhesion 109 occurs when a free-floating blastocyst comes into contact with the 110 endometrium during the 'receptive window' in which it is able to respond to 111 the signals from the blastocyst. This contact is then stabilized in a process 112 known as adhesion in which the trophoblast cells establish contact with the 113 micro protrusions present on the surface of the endometrium known as 114 pinopodes $^{13}$. The last step of implantation is the invasion process, which 115 involves penetration of the embryo through the luminal epithelium into the 116 endometrial stroma; this activity is mainly controlled by the trophoblast.

117 The trophoblast lineage is the first to differentiate during human 118 development, at the transition between morula and blastocyst. Initially, at 119 day 6 to 7 post-conception, a single layer of mononucleated trophoblast cells 
120 surrounds the blastocoel and the inner cell mass. At the site of attachment

121 and direct contact to maternal tissues, trophoblast cells fuse to form a 122 second layer of postmitotic multinucleated syncytiotrophoblast ${ }^{14}$. Once

123 formed, the syncytiotrophoblast grows by means of steady incorporation of

124 new mononucleated trophoblast cells from a proximal subset of stem cells 125 located at the cytotrophoblast layer ${ }^{15}$.

126 Tongues of syncitiotrophoblast cells begin to penetrate the endometrial cells

127 and gradually the embryo is embedded into the stratum compactum of the 128 endometrium. A plug of fibrin initially seals the defect in the uterine surface, 129 but by days 10 to 12 the epithelium is restored ${ }^{16}$. Only at around the $14^{\text {th }}$ day 130 mononucleated cytotrophoblasts break through the syncytiotrophoblast layer 131 and begin to invade the uterine stroma at sites called trophoblastic cell 132 columns. Such cells constitute the extravillous trophoblast, and have at least 133 two main subpopulations: interstitial trophoblast, comprising all those 134 extravillous trophoblast cells that invade uterine tissues and that are not 135 located inside vessel walls and lumina; and endovascular trophoblast, 136 located inside the media or lining the spiral artery lumina and partly 137 occluding them (sometimes this subtypes is further subdivided into 138 intramural and endovascular trophoblast $)^{16}$.

139 At a molecular level, trophoblast adhesion from the stage of implantation 140 onwards is an integrin-dependent process ${ }^{17,}{ }^{18}$ that takes place in a 141 chemokine- and cytokine- rich microenvironment analogous to the blood142 vascular interface. Of note, in human, uterine expression of chemokines is 143 hormonally regulated and the blastocyst expresses chemokine receptors. In 144 addition, oxygen tension plays an important role in guiding the differentiation 145 process that leads to cytotrophoblast invasion to the uterus ${ }^{19,20}$.

$146 \mathbf{3 . 2}$ What is the role of heparin and heparin derived molecules in the 147 process of implantation?

148 Heparin and heparin derived molecules influence all stages of implantation.

149 This anticoagulant has an effect on the expression of adhesion molecules, 150 matrix degrading enzymes and trophoblast phenotype and apoptosis (see 151 table 2). 


\section{3.2.1 Selectins and Cadherins}

153 Selectins and cadherins families are the main adhesion molecules

154 investigated with regard to the implantation process. Selectins are a group of 155 three carbohydrate-binding proteins that are named following the cell type 156 expressing them (E- endothelium, P- platelets, and L- leucocytes): E-selectin 157 is expressed on the endothelial surface; P-selectin on the surface of activated 158 platelets; and L-selectin on lymphocytes, where it plays an essential role in 159 the homing mechanism of these cells ${ }^{21,22}$. The selectins adhesion system may 160 constitute an initial step in the implantation process. Indeed, L-selectin is 161 strongly expressed on the blastocyst surface while, during the window of 162 implantation, there is an up-regulation in the decidual expression of the 163 selectin oligosaccharide-based ligands, predominantly on endometrial luminal 164 epithelium ${ }^{23}$. This may assist in the blastocyst decidual apposition during the 165 implantation process.

166 The effect of heparin on selectins during implantation is unclear. Due to its 167 high density in negatively charged sulfates and carboxylates, heparin is able 168 to bind the two binding sites of the natural ligand of selectin molecules ( $P$ 169 and L-selectins) (one for the sialyl Lewis $X$ moiety and another for the 170 tyrosine sulfate-rich region of its native ligand P-selectin glycoprotein ligand-1 171 [PSGL-1]), and the number of sites bonded is dependent on the length of the 172 heparin chain. Evidence in support is presented by the study of Stevenson et $173 \mathrm{al}^{24}$ who investigated the effect of different unfractionated heparin and LMWH 174 on selectin molecules in cancer cell lines. Tinzaparin, with $22 \%$ to $36 \%$ of 175 fragments greater than 8 kDA, significantly impaired L-selectin binding to its 176 ligand; whereas enoxaparin, with $0 \%$ to $18 \%$ fragments greater than $8 \mathrm{kDa}$, 177 did not affect L-selectin expression ${ }^{24}$. Thus, heparins with high proportion of 178 fragments longer than $8 \mathrm{kDa}$ may reduce inflammatory cell adhesion and 179 homing, on the other hand they may affect blastocyst adhesion by blocking 180 selectins ligand binding sites.

181 Cadherins are a group of cell adhesion proteins that mediate $\mathrm{Ca}^{2+}$-dependent 182 cell-cell adhesion, a fundamental process required for blastocyst implantation 183 and embryonic development ${ }^{25}$. E- cadherin plays an important 184 role in maintaining cell adhesion. In cancer cells, the reduction of E-cadherin 
185 expression promotes acquisition of invasive phenotype. Interestingly, 186 gestational trophoblastic diseases (choriocarcinoma and complete

187 hydatidiform mole) that are characterized by invasive trophoblast behavior 188 has a lower E-cadherin trophoblastic expression than that of first-trimester 189 placenta ${ }^{26}$. In contrast, the trophoblast expression of E-cadherin is higher in 190 placentas of patients with preeclampsia, than in those of normal pregnant 191 women $^{27}$. The effect of heparin on E-cadherin expression was studied by 192 Erden and coworkers $^{28}$, who randomly treated female rats with different 193 heparins (UFH, enoxaparin, and tinzaparin) during the preconceptional 194 period, and examined E-cadherin expression in tissue sections of placenta 195 and decidua from the different groups. The group treated by UFH had a lower 196 E-cadherin placental staining than other study groups. In addition, the 197 decidual staining score of this molecule was lower both in the UFH and 198 Enoxaparin groups in comparison to controls and rats treated with tinzaparin. 199 Therefore, there is evidence to support the effect of heparins on trophoblast 200 invasiveness through E-cadherin expression, providing a possible mechanism 201 by which heparin could promote trophoblast cell differentiation and motility.

$202 \quad 3.2 .2$ Heparin binding EGF-like growth factor

203 Heparin-binding EGF-like growth factor (HB-EGF) is a 76-86 amino acid 204 glycosylated protein that was originally cloned from macrophage-like U937 205 cells. It is a member of the epidermal growth factor (EGF) family that 206 stimulates growth and differentiation. HB-EGF utilizes various molecules as its 207 "receptors". The primary receptors are in the ErbB (also named HER) system, 208 especially ErbB1 and ErbB4, human tyrosine kinase receptors. HB-EGF is 209 initially synthesized as a transmembrane precursor protein, similar to other 210 members of the EGF family of growth factors. The membrane-anchored form 211 of HB-EGF (pro HB-EGF) is composed of a pro domain followed by heparin212 binding, EGF-like, juxtamembrane, transmembrane and cytoplasmic domains. 213 Subsequently, proHB-EGF is cleaved at the cell surface by a protease to yield 214 the soluble form of HB-EGF (sHB-EGF) using a mechanism known as 215 ectodomain shedding. SHB-EGF is a potent mitogen and chemoattractant for 216 a number of different cell types. Studies of mice expressing non-cleavable 
217 HB-EGF have indicated that the major functions of HB-EGF are mediated by 218 the soluble form ${ }^{29}$.

219 Heparin-binding epidermal-growth-factor-like growth factor (HB-EGF) 220 accumulates in the trophoblast ${ }^{30}$ throughout the placenta $^{31}$. Multiple roles for 221 heparin binding epidermal growth factor-like growth factor are suggested by 222 its cell specific expression during the human endometrial cycle and early 223 placentation, and high levels expression in the first trimester ${ }^{32}$.

224 The membrane active precursor functions as a justacrine growth factor and

225 cell-surface receptor. It has been demonstrated to promote adhesion of the 226 blastocyst to the uterine wall in a mouse-in-vitro- system ${ }^{33}$ suggesting a role

227 for HB-EGF in embryo attachment to the uterine luminal epithelium. As stated 228 above, the majority of HB-EGF's biological functions are mediated by its 229 mature soluble form. A major role in early stages of placentation is 230 represented by cellular differentiation and consequent invasion of the uterine 231 wall and vascular network.

232 Several changes occur in the expression of adhesion molecules as 233 cytotrophoblast differentiation proceeds, which results in 234 pseudovasculogenesis or the adaptation by cytotrophoblast of a molecular 235 phenotype that mimics endothelium ${ }^{18}$. For example, during extravillous 236 differentiation in vivo, integrin expression is altered from predominantly $\alpha 6 \beta 4$ 237 in the villous trophoblast to $\alpha 1 \beta 1$ in cytotrophoblasts migrating throughout 238 the decidual stroma ${ }^{17}$ or engaging in endovascular invasion ${ }^{18}$.

239 Leach et $\mathrm{al}^{34}$ demonstrated the role of HB-EGF in regulating the conversion of 240 human cytotrophoblasts into invasive phenotype and the motility of these 241 cells. This study demonstrated the ability of HB-EGF to induce 'integrin 242 switching' through intracellular signaling induced by ligation of HER tyrosine 243 kinases, alters integrin gene expression to stimulate cytotrophoblast invasion 244 at a molecular level.

245 In addition to its effect on the invasive trophoblast phenotype, HB-EGF can 246 affect cell motility. Indeed, cytotrophoblasts motility was specifically 247 increased by each of the EGF family members examined. The expression by 248 cytotrophoblasts of each growth factor, as well as their receptors, suggests 249 the possibility of an autocrine loop that advances cytotrophoblast 250 differentiation to the extravillous phenotype. 
251 The ability of HB-EGF molecule to prevent hypoxic induced apoptosis plays a 252 fundamental role in early stages of placentation. During the entire $1^{\text {st }}$ 253 trimester, the organogenesis period, embryonic development takes place in a 254 low $\mathrm{O}_{2}$ tension environment. Oxygen concentration is relatively low ( $18 \mathrm{mmHg}$ 255 or $2 \%$ ) at the human implantation site through the first 10 weeks of gestation 256 due to occlusion of the uterine spiral arteries by extravillous trophoblasts.

257 Oxygen availability serves as a developmental cue to regulate trophoblast 258 proliferation. Experimental evidence suggests that this environment is 259 essential for both fetal and placental development, and premature exposure 260 to normal oxygen concentrations is associated with increased rate of 261 pregnancy complications such as preeclampsia, IUGR and miscarriage ${ }^{35}$.

262 First trimester human cytotrophoblast cell survival at $2 \% 02$ is dependent on 263 HB-EGF signaling ${ }^{36}$. Indeed, HB-EGF expression is up regulated by hypoxia, 264 and it functions as a mitogen and potent cell survivor factor during stress. 265 The mechanism proposed for this effect of HB-EGF is as follows: sHB-EGF is 266 released by activated metalloproteinases that cleave the extracellular 267 domain of pro- HB-EGF. SHB-EGF binds to HER1 or HER4 through its EGF-like 268 domain and to heparin sulfate proteoglicans (HSPG) through its heparin 269 binding domain, and this is followed by receptor homo- or heterodimerization 270 with other members of the HER family. Subsequent transphosphorylation of 271 HER cytoplasmatic domains at tyrosine residues initiates a downstream 272 signaling that increases proHB-EGF accumulation and inhibits apoptosis. This 273 positive feedback loop upregulates HBEGF secretion to achieve extracellular 274 HB-EGF levels sufficient to maintain cell survival at $2 \% \mathrm{O}^{36}$.

275 As a result HB-EGF has a fundamental role in successful pregnancies. This 276 molecule mediates a vast number of functions beginning from the earliest 277 stages of pregnancy; from adhesion, to implantation and invasion, successful 278 placentation, and protection from hypoxic induced aptoptosis from early 279 stages and up to term. The effect of heparin on this molecule is currently 280 being studied. Di Simone et $\mathrm{al}^{37}$ demonstrated that LMWH induced an 281 increased decidual expression and secretion of HB-EGF in a dose-dependent 282 manner. In a different study by D'ippolito et al ${ }^{38}$ demonstrated that LMWH 283 induces activation of Activator Protein-1 (AP-1), a DNA-binding transcription 
284 factor which regulates the expression of HB-EGF. Activated AP-1 translocates 285 to the nucleus and binds the promoter region of HB-EGF gene thus 286 enhancing its protein expression. Hills and Abrahams ${ }^{39}$ demonstrate that 287 heparin is capable of activating the EGF receptor in primary villous 288 trophoblast.

289 Thus, we propose that the accumulating evidence suggests that the 290 beneficial effect of heparin in preventing placental mediated pregnancy 291 complications may derive from its effect on HB-EGF expression and

292 concentration, especially during the first trimester.

293 3.2.3 Matrix metalloproteinases

294 In addition to the adhesion molecules, matrix metalloproteinases (MMPs) are 295 an important component in the process of blastocyst implantation. MMPs are 296 a group of matrix degrading enzymes which are secreted as inactive 297 zymogen and must be cleaved to become active ${ }^{40}$. Among the members of 298 the MMP family, MMP-2 and MMP-9 type IV collagenases were suggested to 299 be involved in trophoblast invasion into endometrial tissues ${ }^{41}$. Indeed, the 300 profile of pro-MMP 2 and 9 secretion differs during the stages of trophoblast 301 invasion and implantation, and differences in these zymogens expression 302 were found between 6-8 and 9-12 weeks of gestation in extravillous 303 cytotrophoblast cells ${ }^{42}$. Di Simone et al investigated the effect of LWMH 304 specifically on placental MMPS ${ }^{43}$, and the degrading capacity of the 305 trophoblast cells. This effect is mediated by heparins action on both 306 metalloproteinases (MMPs) and their tissue inhibitors (TIMPs). Heparin 307 increased both the MMPs concentration and activity by affecting their 308 transcription, conversion of the proenzyme into the active form, and 309 reduction of the synthesis of the specific inhibitors TIMPs (both the mRNA and 310 protein levels) in a dose dependent manner ${ }^{43}$.

\section{$311 \quad 3.3$ Immunologic and anti-inflammatory effects of heparins}

312 Immune tolerance of the semi-allogeneic fetus is prerequisite for a successful 313 pregnancy outcome ${ }^{44}$. The maternal blood is in direct contact with the 314 syncytiotrophoblast at the intervillous space. In addition, the extravillous 315 trophoblast that anchors the placenta to the decidua, and further 
316 differentiate into endovascular trophoblast that invades spiral arteries and

317 remodels the vessel walls is also in direct contact with the maternal blood ${ }^{45-47}$.

318 Both innate and adaptive immune responses contribute to a maternal fetal

319 cross-talk that balances the anti- and pro-inflammatory processes in the feto-

320 maternal interface ${ }^{45}$, ${ }^{48}$. including: MHC class I molecules, hormones,

321 complement regulatory proteins, immunoregulatory molecules (i.e.

322 indolamine 2,3-dioxygenase, Fas/Fas- Ligand, IL-10), regulatory T cells (CD4+

323 CD25+ Foxp $3+$ ), regulatory macrophages, and growth factors expressed at

324 the placental-decidual interface ${ }^{49-56}$. These mechanisms act in concert to

325 sustain the maternal tolerance to the semi-allogenic placenta and fetus ${ }^{57}$. In

326 addition to its well-understood anticoagulant activity, heparin also has an

327 impact on the immune system ${ }^{58-60}$. The main known effect of heparin is on the

328 migration and adhesion of leukocytes during an inflammatory response ${ }^{24}$.

329 The anti-inflammatory effects of heparin are derived from several

330 mechanisms: 1) the molecular structure of heparin is so that upon its

331 bounding to the endothelial cells of blood vessels it creates a negatively

332 charged surface that is facing the vessel lumen. These negatively charge

333 molecules repulse the negatively charge leukocytes and prevent their

334 adhesion to the endothelium (heparan sulfate molecules that are expressed

335 on leukocytes surface are responsible for the negative charge of these cells);

336 2) heparin is a large molecule that can bind a substantial number of proteins

337 which play an important role in inflammation including selectins ( $L$ - selectin ${ }^{61}$

338 and P-selectin molecules ${ }^{62}$ ) and integrins. The B2-integrin adhesion molecule

$339 \mathrm{CD} 11 \mathrm{~b} / \mathrm{CD} 18$, also known as Macrophage antigen 1 (MAC1), is a member of

340 a subfamily of related cell-surface glycoproteins that coordinate adhesive

341 functions including leukocyte migration ${ }^{63}$. Mac1 is expressed on myeloid cells

342 and binds to molecules as intercellular adhesion molecule 1 (ICAM1),

343 fibrinogen, $\mathrm{iC} 3 \mathrm{~b}$, and factor $\mathrm{Xa}$. The heparin-Mac1 bond interferes with

344 myeloid cell adhesion and transmigration ${ }^{64}$. Heparin also binds to

345 platelet/endothelial cell adhesion molecule 1 (PECAM1), a member of the Ig 346 superfamily, expressed on a variety of cells such as platelets, endothelia,

347 monocytes, neutrophils, T-cell subsets and granulocyte/macrophage 
348 precursors. This molecule is involved in homotypic and heterotypic cellular

349 adhesion and plays a role in the transmigration of inflammatory cells through 350 the endothelial wall. Heparin is capable of binding PECAM1 and interfering 351 with its action $^{65}$, reducing by that the effectiveness of the inflammatory 352 response.

353 The anti-inflammatory properties of LMWH have been demonstrated within in 354 vivo models. Indeed, Wang et al ${ }^{66}$ investigated the effects of LMWH on 355 dextran sulfate sodium (DSS)-induced colitis in a mice model. The authors 356 reported that mice which were treated with $L M W H$ had a significant decrease 357 in the expression of both IL-1 $\beta$ and of IL-10 mRNA, leading to a down 358 regulation of inflammatory cytokines production. Of interest, LMWH also 359 imitate the function of Syndecan-1 (a protein that is inversely correlated to 360 the mRNA expression of IL-1 $\beta$ in the intestinal mucosa of DSS-induced 361 colitis), a protein which plays an important role in promoting wound repair, 362 maintaining cell morphogenesis, and mediating inflammatory responses ${ }^{67}$ by 363 aiding the clearance of pro-inflammatory chemokines. In addition Li et al ${ }^{68}$ 364 found that treatment with UFH can attenuate inflammatory responses of 365 lypopolisaccharide induced acute lung injury in rats. The mechanisms by 366 which UFH exerts its anti-inflammatory effect seem to correlate with its 367 inhibition of IL-1ß and IL- 6 production via inactivation of the NF-KB pathways. 368 In humans the anti-inflammatory activity of heparin has been evidenced by 369 small clinical trials in patients suffering from a range of inflammatory 370 diseases $^{69}$, including rheumatoid arthritis and bronchial asthma. Remission of 371 disease has been described in nine of ten patients with refractory ulcerative 372 colitis treated with combined heparin and sulphasalazine ${ }^{69}$. A subjective 373 improvement of asthma symptoms using intravenous heparin is described ${ }^{70}$, 374 11, while other studies with inhaled heparin demonstrated reduced 375 bronchoconstrictive responses in patients with exercise-induced asthma ${ }^{72,73}$. 376 The clinical rationale for the use of heparin in the treatment of inflammatory 377 diseases may be based on the fact that many of the molecular mechanisms 378 involved in tumor metastasis are the same responsible for cell recruitment in 379 inflammation; and heparin has been successful in treating both conditions ${ }^{74}$. 
381 pregnancy: In light of the possible effects of heparins and heparin binding 382 molecules on the blastocyst implantation and placentation, this family of 383 drugs may play a role in the prevention of RIF in IVF patients and in the 384 treatment of patients with RPL.

385

386

387

388

389

390

391

392

393

394

395

396

397

398

399

400

401

402

403

404

405

406

407

408

409

410

411

412

\subsection{Is there a benefit of the use of heparins in the prevention of} recurrent implantation failure in IVF patients?

The term RIF has been used since 1983 to describe the failure of embryos to implant following IVF treatments. There is no unanimous definition for RIF in terms of the number of failed cycles or the total number of transferred embryos that have not successfully implanted. The ESHRE PGD consortium document $^{75}$ mentioned that RIF can be considered after more than three high-quality embryo transfers or implantation failure with transfer of $\geq 10$ embryos in multiple transfers with exact numbers to be determined by each center. In order to improve pregnancy outcomes in women with RIF, various investigations and treatment adjuncts including heparin have been studied.

A recent meta-analysis with systematic review of the literature ${ }^{76}$ included $^{2}$ randomized controlled, quasi-randomized and prospective studies comparing the use of LMWH with placebo or no adjuvant treatment in women with RIF undergoing IVF/ICSI. After the process of literature search and selection, one quasi-randomized $^{76}$ and two randomized ${ }^{77,} 78$ studies were selected for the meta-analysis and included 243 women with RIF who underwent IVF/ICSI, 127 in the intervention group and 116 in the control/placebo.

All three studies were unclear for detection bias and none of the studies explicitly stated whether the individuals assessing the outcome were blinded to the trial or not. However, assessment for pregnancy outcome is unlikely to be subjective since implantation, clinical pregnancy, multiple pregnancies and miscarriage are all objectively assessed on ultrasound scan.

The results of this meta-analysis show that in women with $\geq 3 \mathrm{RIF}$, the use of LMW as an adjunct to IVF treatment significantly improved the life birth rate by $79 \%$.

This result suggests that there could be a potential role of LMWH in improving pregnancy outcomes for women with RIF. 
413 4.2 What is the effect of heparins on pregnancy success in women 414 with recurrent pregnancy loss?

415 A beneficial effect of antithrombotic agents, heparin in particular, in women 416 with RPL was suggested already in $1980^{79}$. Different clinical definitions of this 417 condition are achieved by the different scientific societies: the Royal College 418 of Obstetricians and Gynecologists (RCOG) considers three or more first 419 trimester miscarriages as RPL, while the American Society for Reproductive 420 Medicine (ASRM) establishes a limit of two or more pregnancy losses.

421 Many underlying mechanisms have been recognized for RPL, including 422 chromosomal defects ${ }^{80}$, endocrinopathies ${ }^{81}$ (thyroid diseases and diabetes), 423 uterine malformations ${ }^{82}$, and autoimmune diseases ${ }^{83}$. In addition, 424 thrombophilic mutations ${ }^{84}$ have been suggested as leading to alterations in 425 embryonic formation, migration, implantation and placentation and, in the 426 past three decades, this area became a field of extensive study, with the goal 427 of increasing the rate of live births in these patients.

428 Conflicting results are provided from the studies performed to address this 429 question. This is also a consequence of the marked heterogeneity among the 430 different studies. Evidence in support of this view is brought by several 431 experiences including prospective ${ }^{85}$ and retrospective $^{86}$ cohort studies, 432 evaluating the benefit of treatment with heparin in patients with RPL, in 433 terms of live birth rate. Moreover, due to several criticisms contained in the 434 study design, there was the need for randomized clinical trials further 435 addressing the question regarding whether heparins could be beneficial in 436 patients with RPL, comparing the outcome of live birth rate among treated 437 and untreated women. The following RCTs were performed to the purpose, 438 including both patients with or without inherited thrombophilia: 1) In the 439 LIVE-ENOX study ${ }^{87}, 180$ women with thrombophilia and RPL were randomized 440 to either enoxaparin 40 or $80 \mathrm{mg}$ once daily. In addition to inherited 441 thrombophilia, women with antiphospholipid antibodies, MTHFR 677TT 442 genotype and hyperhomocysteinemia were eligible. The live birth rates in 443 both groups were similar (84.3\% and $78.3 \%$, respectively), but as a control 444 group was lacking, the effect of enoxaparin could not be validated; 2 ) In 
445 2006, Dolitzky et al $^{88}$ randomized 54 patients with RPL either to treatment 446 with enoxaparin or aspirin, considering subsequent live births or miscarriage 447 as the main outcome. Both groups had a similar live birth rate (relative 448 risk $=0.92,95 \% \mathrm{Cl} 0.58-1.46)$. Of interest, this study showed that, even 449 though there was not statistical difference between the study groups, women 450 who were treated by heparins had a higher live birth rate to that reported in 451 literature in women with RPL; 3) The ALIFE study ${ }^{89}$ included 364 women with 452 two or more unexplained pregnancy losses that were randomized to 453 nadroparin 2850 International Unit combined with aspirin $80 \mathrm{mg}$, aspirin 80 $454 \mathrm{mg}$ only, or a placebo before conception or at a maximum gestational age of 4556 weeks. Of these women, 299 became pregnant. The chance of live birth did 456 not differ among the treatment groups. The relative risk of live birth for 457 women who became pregnant was 1.03 (95\% Cl 0.85- 1.25) for nadroparin 458 combined with aspirin, and 0.92 (95\% Cl 0.75-1.13) for aspirin only compared 459 with placebo. The study was not designed to evaluate the beneficial effect of 460 heparin on thrombophilic patients but the author performed a secondary 461 analysis of the effect of heparins according toi the presence of inherited 462 thrombophilia, showing no significant difference in the primary outcome 463 among the groups; 4) A randomized double-blind (for aspirin) multicenter 464 trial $^{90}$ was performed among 207 women with three or more consecutive first 465 trimester ( $<13$ weeks) miscarriages, two or more second trimester (13-24 466 weeks) miscarriages or one third trimester fetal loss combined with one first 467 trimester miscarriage. Women underwent workup for thrombophilia and were 468 randomly allocated before seven weeks' gestation to either enoxaparin 40 $469 \mathrm{mg}+$ placebo $(\mathrm{n}=68)$, enoxaparin $40 \mathrm{mg}+$ aspirin $100 \mathrm{mg}(\mathrm{n}=63)$ or aspirin $470100 \mathrm{mg}(\mathrm{n}=76)$. The primary outcome was the live-birth rate. The trial was 471 stopped prematurely because of slow recruitment. A live birth rate of $71 \%$ 472 [RR 1.17, 95\% Cl 0.92-1.48] was found for enoxaparin and placebo and $65 \%$ 473 [RR 1.08, 95\% Cl 0.83-1.39] for enoxaparin and aspirin when compared to 474 aspirin alone (61\%, reference group). In the whole study group the live birth 475 rate was $65 \%(95 \% \mathrm{Cl} 58.66-71.74)$ for women with three or more 476 miscarriages $(n=204)$. No difference in pregnancy complications, neonatal 
477 outcome or adverse effects was observed. No significant difference in live

478 birth rate was found with enoxaparin treatment versus aspirin or a

479 combination of both versus aspirin in women with recurrent miscarriage.

480 Little evidence is available for the effect of antithrombotic agents in women

481 with a single pregnancy loss and inherited thrombophilia. The results from 482 several small retrospective and prospective cohort studies in women with 483 inherited thrombophilia, with or without previous pregnancy complications, 484 suggest a beneficial effect of antithrombotic therapy to reduce pregnancy 485 complications ${ }^{91,92}$. These studies are heterogeneous with regard to study 486 design and study population.

\section{5. Conclusion}

488 Heparins play a role in embryonic implantation and placentation and 489 contribute to the development of a normal pregnancy. This effect is gained 490 through the interaction of heparins with coagulation factors, anticoagulation 491 proteins, their effect on the expression of adhesion molecules, matrix 492 degrading enzymes and trophoblast phenotype and apoptosis, all important 493 components in the process of embryonic implantation and placentation.

494 The fact that heparins may play a role in implantation and placentation, led 495 to their use in the prevention of RIF and RPL. In RIF heparins demonstrated a 496 beneficial effect that could be attributed to the effects of this molecule on 497 enhancing endometrial receptivity and trophoblast invasion due to the 498 regulation of heparin-binding factors, adhesion molecules or inhibition of 499 complement activation. In contrast, the positive effect of heparin as a 500 treatment for RPL is not that clear. One possible explanation for this lack of 501 conclusive evidence is the syndromic nature of RPL which results from 502 several underlying mechanisms of disease. Thus, heparins may have a role in 503 improving pregnancy outcomes among a subset of patients with RPL 504 regardless to the presence of thrombophilia, but a conclusive statement in 505 this matter awaits further investigation. 506 
508 1. Romero R, Dekker G, Kupferminc M, Saade G, Livingston J, Peaceman A, Mazor 509 M, Yoon BH, Espinoza J, Chaiworapongsa T, Gomez R, Arias F, Sibai B. Can heparin prevent adverse pregnancy outcome? J Matern Fetal Neonatal Med 2002;12:1-8.

2. Linhardt RJ. Heparin: an important drug enters its seventh decade. Chem Indust 1991;2:45-50.

3. Marcum JA, McKenney JB, Galli SJ, Jackman RW, Rosenberg RD. Anticoagulantly active heparin-like molecules from mast cell-deficient mice. Am J Physiol 1986;250:H879-88.

4. Nader HB, Chavante SF, dos-Santos EA, Oliveira TW, de-Paiva JF, Jerônimo SM, Medeiros GF, de-Abreu LR, Leite EL, de-Sousa-Filho JF, Castro RA, Toma L, Tersariol IL, Porcionatto MA, Dietrich CP. Heparan sulfates and heparins: similar compounds performing the same functions in vertebrates and invertebrates? Braz J Med Biol Res 1999;32:529-38.

5. Rosenberg RD, Bauer KA. The heparin-antithrombin system: a natural anticoagulant mechanism. In: Colman RW, Hirsh J, Marder VJ, et al, eds. Hemostasis and thrombosis: basic principles and clinical practice. Philadelfia: JB Lippincott, 1992.

6. Rosenberg RD, Jordan RE, Favreau LV, Lam LH. Highly active heparin species with multiple binding sites for antithrombin. Biochem Biophys Res Commun 1979;86:1319-24.

7. Björk I, Lindahl U. Mechanism of the anticoagulant action of heparin. Mol Cell Biochem 1982;48:161-82.

8. Petitou M, Duchaussoy P, Lederman I, Choay J, Jacquinet JC, Sinaÿ P, Torri G. Synthesis of heparin fragments: a methyl alpha-pentaoside with high affinity for antithrombin III. Carbohydr Res 1987;167:67-75.

9. Petitou M, Duchaussoy P, Jaurand G, Gourvenec F, Lederman I, Strassel JM, Bârzu T, Crépon B, Hérault JP, Lormeau JC, Bernat A, Herbert JM. Synthesis and pharmacological properties of a close analogue of an antithrombotic pentasaccharide (SR 90107A/ORG 31540). J Med Chem 1997;40:1600-7.

10. Weitz JI. Low-molecular-weight heparins. N Engl J Med 1997;337:688-98.

11. Chang CH, Lico LS, Huang TY, Lin SY, Chang CL, Arco SD, Hung SC. Synthesis of the Heparin-Based Anticoagulant Drug Fondaparinux. Angew Chem Int Ed Engl 2014;53:9876-9.

12. Dey SK, Lim H, Das SK, Reese J, Paria BC, Daikoku T, Wang H. Molecular cues to implantation. Endocr Rev 2004;25:341-73.

13. Lopata A, Bentin-Ley U, Enders A. "Pinopodes" and implantation. Rev Endocr Metab Disord 2002;3:77-86.

14. Hoozemans DA, Schats R, Lamblack CB, Homburg R, Hompes PG. Human embryo implantation: current knowledge and clinical implications in assisted reproductive technology. Reprod Biomed Online 2004;9:692-715.

15. Jauniaux E. Design, beauty and differentiation: the human fetus during the first trimester of gestation. Reprod Biomed Online 2000;1:107-8.

16. Hertig AT, Rock J, Adams EC. A description of 34 human ova within the first 17 days of development. Am J Anat 1956;98:435-93.

17. Damsky $\mathrm{CH}$, Fitzgerald ML, Fisher SJ. Distribution patterns of extracellular matrix components and adhesion receptors are intricately modulated during first trimester cytotrophoblast differentiation along the invasive pathway, in vivo. J Clin Invest 1992;89:210-22. 
557 18. Zhou Y, Fisher SJ, Janatpour M, Genbacev O, Dejana E, Wheelock M, Damsky

$558 \mathrm{CH}$. Human cytotrophoblasts adopt a vascular phenotype as they

559

560

561

562

563

564

565

566

567

568

569

570

571

572

573

574

575

576

577

578

579

580

581

582

583

584

585

586

587

588

589

590

591

592

593

594

595

596

597

598

599

600

601

602

603

604

605

606

607

608

609 differentiate. A strategy for successful endovascular invasion? J Clin Invest 1997;99:2139-51.

19. Lash GE, Otun HA, Innes BA, Bulmer JN, Searle RF, Robson SC. Low oxygen concentrations inhibit trophoblast cell invasion from early gestation placental explants via alterations in levels of the urokinase plasminogen activator system. Biol Reprod 2006;74:403-9.

20. Zhao H, Jiang Y, Cao Q, Hou Y, Wang C. Role of integrin switch and transforming growth factor Beta 3 in hypoxia-induced invasion inhibition of human extravillous trophoblast cells. Biol Reprod 2012;87:47.

21. Rosen SD. Ligands for L-selectin: homing, inflammation, and beyond. Annu Rev Immunol 2004;22:129-56.

22. Rosen SD. Homing in on L-selectin. J Immunol 2006;177:3-4.

23. Genbacev OD, Prakobphol A, Foulk RA, Krtolica AR, llic D, Singer MS, Yang ZQ, Kiessling LL, Rosen SD, Fisher SJ. Trophoblast L-selectin-mediated adhesion at the maternal-fetal interface. Science 2003;299:405-8.

24. Stevenson JL, Choi SH, Varki A. Differential metastasis inhibition by clinically relevant levels of heparins--correlation with selectin inhibition, not antithrombotic activity. Clin Cancer Res 2005;11:7003-11.

25. Frenette PS, Wagner DD. Adhesion molecules--Part 1. N Engl J Med 1996;334:1526-9.

26. Xue WC, Feng HC, Tsao SW, Chan KY, Ngan HY, Chiu PM, Maccalman CD, Cheung AN. Methylation status and expression of E-cadherin and cadherin-11 in gestational trophoblastic diseases. Int J Gynecol Cancer 2003;13:879-88.

27. Li HW, Cheung AN, Tsao SW, Cheung AL, O WS. Expression of e-cadherin and beta-catenin in trophoblastic tissue in normal and pathological pregnancies. Int J Gynecol Pathol 2003;22:63-70.

28. Erden O, Imir A, Guvenal T, Muslehiddinoglu A, Arici S, Cetin M, Cetin A. Investigation of the effects of heparin and low molecular weight heparin on Ecadherin and laminin expression in rat pregnancy by immunohistochemistry. Hum Reprod 2006;21:3014-8.

29. Miyamoto S, Yagi H, Yotsumoto F, Kawarabayashi T, Mekada E. Heparinbinding epidermal growth factor-like growth factor as a novel targeting molecule for cancer therapy. Cancer Sci 2006;97:341-7.

30. Cha J, Sun X, Dey SK. Mechanisms of implantation: strategies for successful pregnancy. Nat Med 2012;18:1754-67.

31. Leach RE, Khalifa R, Ramirez ND, Das SK, Wang J, Dey SK, Romero R, Armant DR. Multiple roles for heparin-binding epidermal growth factor-like growth factor are suggested by its cell-specific expression during the human endometrial cycle and early placentation. J Clin Endocrinol Metab 1999;84:3355-63.

32. YoO HJ, BARLOW DH, MARDON HJ. Temporal and spatial regulation of expression of heparin-binding epidermal growth factor-like growth factor in the human endometrium: a possible role in blastocyst implantation. Dev Genet 1997;21:102-8.

33. RAAB G, KLAGSBRUN M. Heparin-binding EGF-like growth factor. Biochim Biophys Acta 1997; 1333:F179-99.

34. Leach RE, Kilburn B, Wang J, Liu Z, Romero R, Armant DR. Heparin-binding EGFlike growth factor regulates human extravillous cytotrophoblast development during conversion to the invasive phenotype. Dev Biol 2004;266:223-37.

35. Jauniaux E, Hempstock J, Greenwold N, Burton GJ. Trophoblastic oxidative stress in relation to temporal and regional differences in maternal placental 

Scambia G, Di Simone N. Emerging nonanticoagulant role of low molecular weight heparins on extravillous trophoblast functions and on heparin bindingepidermal growth factor and cystein-rich angiogenic inducer 61 expression. Fertil Steril 2012;98:1028-36.e1-2.

39. Hills FA, Abrahams VM, González-Timón B, Francis J, Cloke B, Hinkson L, Rai R, Mor G, Regan L, Sullivan M, Lam EW, Brosens JJ. Heparin prevents programmed cell death in human trophoblast. Mol Hum Reprod 2006;12:23743.

40. Isaka K, Usuda S, Ito H, Sagawa Y, Nakamura H, Nishi H, Suzuki Y, Li YF, Takayama M. Expression and activity of matrix metalloproteinase 2 and 9 in human trophoblasts. Placenta 2003;24:53-64.

41. Librach CL, Werb Z, Fitzgerald ML, Chiu K, Corwin NM, Esteves RA, Grobelny D, Galardy R, Damsky CH, Fisher SJ. 92-kD type IV collagenase mediates invasion of human cytotrophoblasts. J Cell Biol 1991;113:437-49.

42. Staun-Ram E, Goldman S, Gabarin D, Shalev E. Expression and importance of matrix metalloproteinase 2 and 9 (MMP-2 and -9) in human trophoblast invasion. Reprod Biol Endocrinol 2004;2:59.

43. Di Simone N, Di Nicuolo F, Sanguinetti M, Ferrazzani S, D'Alessio MC, Castellani R, Bompiani A, Caruso A. Low-molecular weight heparin induces in vitro trophoblast invasiveness: role of matrix metalloproteinases and tissue inhibitors. Placenta 2007;28:298-304.

44. Clark DA, Arck PC, Chaouat G. Why did your mother reject you? Immunogenetic determinants of the response to environmental selective pressure expressed at the uterine level. Am J Reprod Immunol 1999;41:5-22.

45. Norwitz ER, Schust DJ, Fisher SJ. Implantation and the survival of early pregnancy. N Engl J Med 2001;345:1400-8.

46. Bischof P, Campana A. A model for implantation of the human blastocyst and early placentation. Hum Reprod Update 1996;2:262-70.

47. Red-Horse K, Zhou Y, Genbacev O, Prakobphol A, Foulk R, McMaster M, Fisher SJ. Trophoblast differentiation during embryo implantation and formation of the maternal-fetal interface. J Clin Invest 2004;114:744-54.

48. Moffett-King A. Natural killer cells and pregnancy. Nat Rev Immunol 2002;2:656-63.

49. Redecha P, Tilley R, Tencati M, Salmon JE, Kirchhofer D, Mackman N, Girardi G. Tissue factor: a link between $\mathrm{C} 5 \mathrm{a}$ and neutrophil activation in antiphospholipid antibody induced fetal injury. Blood 2007;110:2423-31.

50. Thangaratinam S, Tan A, Knox E, Kilby MD, Franklyn J, Coomarasamy A. Association between thyroid autoantibodies and miscarriage and preterm birth: meta-analysis of evidence. BMJ 2011;342:d2616. 
661 51. Wegmann TG, Lin H, Guilbert L, Mosmann TR. Bidirectional cytokine

662

663

664

665

666

667

668

669

670

671

672

673

674

675

676

677

678

679

680

681

682

683

684

685

686

687

688

689

690

691

692

693

694

695

696

697

698

699

700

701

702

703

704

705

706

707

708

709

710

711

712

713

interactions in the maternal-fetal relationship: is successful pregnancy a $\mathrm{TH} 2$ phenomenon? Immunol Today 1993;14:353-6.

52. Thellin O, Coumans B, Zorzi W, Igout A, Heinen E. Tolerance to the foetoplacental 'graft': ten ways to support a child for nine months. Curr Opin Immunol 2000;12:731-7.

53. Li M, Huang SJ. Innate immunity, coagulation and placenta-related adverse pregnancy outcomes. Thromb Res 2009;124:656-62.

54. Mjösberg J, Berg G, Ernerudh J, Ekerfelt C. CD4+ CD25+ regulatory T cells in human pregnancy: development of a Treg-MLC-ELISPOT suppression assay and indications of paternal specific Tregs. Immunology 2007;120:456-66.

55. Karimi K, Blois SM, Arck PC. The upside of natural killers. Nat Med 2008;14:1184-5.

56. Aluvihare VR, Kallikourdis M, Betz AG. Regulatory T cells mediate maternal tolerance to the fetus. Nat Immunol 2004;5:266-71.

57. Kalkunte SS, Mselle TF, Norris WE, Wira CR, Sentman CL, Sharma S. Vascular endothelial growth factor $\mathrm{C}$ facilitates immune tolerance and endovascular activity of human uterine NK cells at the maternal-fetal interface. J Immunol 2009;182:4085-92.

58. Martz E, Benacerraf B. Inhibition of immune cell-mediated killing by heparin. Clin Immunol Immunopathol 1973;1:533-46.

59. Sy MS, Schneeberger E, McCluskey R, Greene MI, Rosenberg RD, Benacerraf B. Inhibition of delayed-type hypersensitivity by heparin depleted of anticoagulant activity. Cell Immunol 1983;82:23-32.

60. Arfors KE, Ley K. Sulfated polysaccharides in inflammation. J Lab Clin Med 1993;121:201-2.

61. Koenig A, Norgard-Sumnicht K, Linhardt R, Varki A. Differential interactions of heparin and heparan sulfate glycosaminoglycans with the selectins. Implications for the use of unfractionated and low molecular weight heparins as therapeutic agents. J Clin Invest 1998;101:877-89.

62. Skinner MP, Lucas CM, Burns GF, Chesterman CN, Berndt MC. GMP-140 binding to neutrophils is inhibited by sulfated glycans. J Biol Chem 1991;266:5371-4.

63. Kishimoto TK, Jutila MA, Berg EL, Butcher EC. Neutrophil Mac-1 and MEL-14 adhesion proteins inversely regulated by chemotactic factors. Science 1989;245:1238-41.

64. Diamond MS, Alon R, Parkos CA, Quinn MT, Springer TA. Heparin is an adhesive ligand for the leukocyte integrin Mac-1 (CD11b/CD1). J Cell Biol 1995;130:1473-82.

65. Watt SM, Williamson J, Genevier H, Fawcett J, Simmons DL, Hatzfeld A, Nesbitt $\mathrm{SA}$, Coombe DR. The heparin binding PECAM-1 adhesion molecule is expressed by CD34+ hematopoietic precursor cells with early myeloid and Blymphoid cell phenotypes. Blood 1993;82:2649-63.

66. Wang XF, Li AM, Li J, Lin SY, Chen CD, Zhou YL, Wang X, Chen CL, Liu SD, Chen Y. Low molecular weight heparin relieves experimental colitis in mice by downregulating IL-1 $\beta$ and inhibiting syndecan-1 shedding in the intestinal mucosa. PLoS One 2013;8:e66397.

67. Götte M. Syndecans in inflammation. FASEB J 2003;17:575-91.

68. Li X, Li Z, Zheng Z, Liu Y, Ma X. Unfractionated heparin ameliorates lipopolysaccharide-induced lung inflammation by downregulating nuclear factor-kB signaling pathway. Inflammation 2013;36:1201-8.

69. Gaffney A, Gaffney P. Rheumatoid arthritis and heparin. Br J Rheumatol 1996;35:808-9. 
714 70. Fine NL, Shim C, Williams MH. Objective evaluation of heparin in the treatment

71. Boyle JP, Smart RH, Shirey JK. Heparin in the treatment of chronic obstructive bronchopulmonary disease. Am J Cardiol 1964;14:25-8.

72. Garrigo J, Danta I, Ahmed T. Time course of the protective effect of inhaled heparin on exercise-induced asthma. Am J Respir Crit Care Med 1996;153:1702-7.

73. Ahmed T, Garrigo J, Danta I. Preventing bronchoconstriction in exerciseinduced asthma with inhaled heparin. N Engl J Med 1993;329:90-5.

74. Tyrrell DJ, Horne AP, Holme KR, Preuss JM, Page CP. Heparin in inflammation: potential therapeutic applications beyond anticoagulation. Adv Pharmacol 1999;46:151-208.

75. Thornhill AR, deDie-Smulders CE, Geraedts JP, Harper JC, Harton GL, Lavery SA, Moutou C, Robinson MD, Schmutzler AG, Scriven PN, Sermon KD, Wilton L. ESHRE PGD Consortium 'Best practice guidelines for clinical preimplantation genetic diagnosis (PGD) and preimplantation genetic screening (PGS)'. Hum Reprod 2005;20:35-48.

76. Potdar N, Gelbaya TA, Konje JC, Nardo LG. Adjunct low-molecular-weight heparin to improve live birth rate after recurrent implantation failure: a systematic review and meta-analysis. Hum Reprod Update 2013;19:674-84.

77. Qublan H, Amarin Z, Dabbas M, Farraj AE, Beni-Merei Z, Al-Akash H, Bdoor AN, Nawasreh M, Malkawi S, Diab F, Al-Ahmad N, Balawneh M, Abu-Salim A. Lowmolecular-weight heparin in the treatment of recurrent IVF-ET failure and thrombophilia: a prospective randomized placebo-controlled trial. Hum Fertil (Camb) 2008;11:246-53.

78. Urman B, Ata B, Yakin K, Alatas C, Aksoy S, Mercan R, Balaban B. Luteal phase empirical low molecular weight heparin administration in patients with failed ICSI embryo transfer cycles: a randomized open-labeled pilot trial. Hum Reprod 2009;24:1640-7.

79. Langer R, Schreyer P, Bukovsky I, Caspi E. Adjuvant anticoagulant therapy in repeated fetal loss. Harefuah 1980;99:65-7.

80. Rajcan-Separovic E, Diego-Alvarez D, Robinson WP, Tyson C, Qiao Y, Harvard C, Fawcett C, Kalousek D, Philipp T, Somerville MJ, Stephenson MD. Identification of copy number variants in miscarriages from couples with idiopathic recurrent pregnancy loss. Hum Reprod 2010;25:2913-22.

81. Ke RW. Endocrine Basis for Recurrent Pregnancy Loss. Obstet Gynecol Clin North Am 2014;41:103-12.

82. Jaslow CR. Uterine Factors. Obstet Gynecol Clin North Am 2014;41:57-86.

83. Kwak-Kim J, Agcaoili MS, Aleta L, Liao A, Ota K, Dambaeva S, Beaman K, Kim JW, Gilman-Sachs A. Management of women with recurrent pregnancy losses and antiphospholipid antibody syndrome. Am J Reprod Immunol 2013;69:596607.

84. Lino FL, Traina E, Barreto JA, Moron AF, Mattar R. Thrombophilic Mutations and Polymorphisms, Alone or in Combination, and Recurrent Spontaneous Abortion. Clin Appl Thromb Hemost 2014.

85. Brenner B, Hoffman R, Blumenfeld Z, Weiner Z, Younis JS. Gestational outcome in thrombophilic women with recurrent pregnancy loss treated by enoxaparin. Thromb Haemost 2000;83:693-7.

86. Carp H, Dolitzky M, Inbal A. Thromboprophylaxis improves the live birth rate in women with consecutive recurrent miscarriages and hereditary thrombophilia. J Thromb Haemost 2003;1:433-8.

87. Brenner B, Hoffman R, Carp H, Dulitsky M, Younis J, InVESTIGATORS L-E. Efficacy and safety of two doses of enoxaparin in women with thrombophilia and 
recurrent pregnancy loss: the LIVE-ENOX study. J Thromb Haemost 2005;3:227-9.

88. Dolitzky M, Inbal A, Segal Y, Weisss A, Brenner B, Carp H. A randomized study of thromboprophylaxis in women with unexplained consecutive recurrent miscarriages. Fertil Steril 2006;86:362-6.

89. Kaandorp SP, Goddijn M, van der Post JA, Hutten BA, Verhoeve HR, Hamulyák K, Mol BW, Folkeringa N, Nahuis M, Papatsonis DN, Büller HR, van der Veen F, Middeldorp S. Aspirin plus heparin or aspirin alone in women with recurrent miscarriage. N Engl J Med 2010;362:1586-96.

90. Visser J, Ulander VM, Helmerhorst FM, Lampinen K, Morin-Papunen L, Bloemenkamp KW, Kaaja RJ. Thromboprophylaxis for recurrent miscarriage in women with or without thrombophilia. HABENOX: a randomised multicentre trial. Thromb Haemost 2011;105:295-301.

91. Kupferminc MJ, Fait G, Many A, Lessing JB, Yair D, Bar-Am A, Eldor A. Lowmolecular-weight heparin for the prevention of obstetric complications in women with thrombophilias. Hypertens Pregnancy 2001;20:35-44.

92. Kupferminc MJ, Fait G, Many A, Lessing JB, Yair D, Bar-Am A, Eldor A. Reduction of high fetal loss rate by anticoagulant treatment during pregnancy in antithrombin, protein $\mathrm{C}$ or protein $\mathrm{S}$ deficient women. $\mathrm{Br}$ J Haematol 2007;136:656-61. 
787 Fig. 1. Antithrombin III after conformational change induced by heparin 788 binding. Reproduced with permission from Whisstoch JC, Pike RN, Jin L, 789 Skinner R, et al. J Mol Biol. 2000; 301:128

790 Fig. 2. Mechanisms of interaction between heparin, antithrombin III, thrombin 791 (A) and factor Xa (B).

792 Table 1. Comparison among low molecular weight heparin preparations (From 793 WEITZ JI. Low-molecular-weight heparins. N Engl J Med 1997;337:688-98. With 794 permission)

795 Table 2. Overview of molecules involved in the process of implantation, 796 trophoblast development and placentation, and effect of heparin on these 797 molecules 


\section{Table $\mathbf{1}$ (on next page)}

Table 1

Table 1. Comparison among low molecular weight heparin preparations (From Weitz Jl. Lowmolecular-weight heparins. N Engl J Med 1997;337:688-98. With permission) 


\section{PeerJ Reviewing Manuscript}

Table 1. Comparison among low molecular weight heparin preparations (From WEITZ Jl. Low-molecular-weight heparins. N Engl J Med 1997;337:688-98. With permission)

\begin{tabular}{|l|l|c|c|}
\hline \multicolumn{1}{|c|}{ PREPARATION } & \multicolumn{1}{|c|}{ METHOD OF PREPARATION } & $\begin{array}{c}\text { MEAN MOLECULAR } \\
\text { WEIGHT }\end{array}$ & $\begin{array}{c}\text { ANTI-XA:ANTI-IIA } \\
\text { RATIO* }\end{array}$ \\
\hline Ardeparin (Normiflo) & Peroxidative depolymerization & 6000 & 1.9 \\
\hline Dalteparin (Fragmin) & Nitrous acid depolymerization & 6000 & 2.7 \\
\hline $\begin{array}{l}\text { Enoxaparin } \\
\text { (Lovenox) }\end{array}$ & Benzylation and alkaline depolymerization & 4200 & 3.8 \\
\hline $\begin{array}{l}\text { Nadroparin } \\
\text { (Fraxiparine) }\end{array}$ & Nitrous acid depolymerization & 4500 & 3.5 \\
\hline Reviparin (Clivarine) & $\begin{array}{l}\text { Nitrous acid depolymerization, chromatographic } \\
\text { purification }\end{array}$ & 4000 & \\
\hline Tinzaparin (Innohep) & Heparinase digestion & 4500 & 1.9 \\
\hline
\end{tabular}

*The ratios were calculated by dividing the anti-factor Xa (anti-Xa) activity by the antithrombin (anti-Ila) activity. The ratios are based on information provided by the manufacturers. 


\section{Table 2 (on next page)}

Table 2

Table 2. Overview of molecules involved in the process of implantation, trophoblast development and placentation, and effect of heparin on these molecules 


\section{PeerJ Reviewing Manuscript}

\section{Table 2. Overview of molecules involved in the process of implantation, trophoblast development and placentation, and effect of heparin on these molecules}

\begin{tabular}{|c|c|c|c|}
\hline Molecule & Site of expression & Activity & Effect of Heparin \\
\hline Anti-thrombin III & $\begin{array}{l}\text { Maternal circulation } \\
\text { Trophoblast }\end{array}$ & $\begin{array}{l}\text { Inactivation of coagulation } \\
\text { factors, including mainly } \\
\text { thrombin (factor Ila), factor Xa, } \\
\text { and factor IXa }\end{array}$ & $\begin{array}{l}\text { Conformational change in AT-III } \\
\text { that accelerates its ability to } \\
\text { inactivate the coagulation } \\
\text { factors }\end{array}$ \\
\hline $\begin{array}{lll}\text { Selectins } & (\mathrm{E}- & \mathrm{P}- \\
\text { and } & & \mathrm{L}- \\
\text { selectins }) & & \end{array}$ & $\begin{array}{l}\text { E-selectin } \\
\text { endothelium, P- } \\
\text { selectin platelets, and } \\
\text { L-selectin leucocytes } \\
\text { and } \\
\text { surface. }\end{array}$ & Cell adhesion and homing & $\begin{array}{l}\text { Interference with inflammatory } \\
\text { cells adhesion and homing but } \\
\text { probable interference with } \\
\text { blastocyst decidual adhesion }\end{array}$ \\
\hline Cadherins & $\begin{array}{l}\text { Trophoblast, placenta, } \\
\text { decidua }\end{array}$ & $\begin{array}{l}\text { Cell adhesion (invasive } \\
\text { phenotype acquired in case of } \\
\text { reduction of expression) }\end{array}$ & Reduction of expression \\
\hline $\begin{array}{l}\text { Heparin-binding } \\
\text { EGF-like growth } \\
\text { factor (HB-EGF) }\end{array}$ & $\begin{array}{l}\text { Trophoblast and } \\
\text { placenta }\end{array}$ & $\begin{array}{l}\text { 1)potent mitogen and } \\
\text { chemoattractant in its soluble } \\
\text { form } \\
\text { promoter of adhesion of the } \\
\text { blastocyst to the uterine wall in } \\
\text { a mouse-in-vitro- system } \\
\text { 2)regulation of the conversion of } \\
\text { human cytotophoblasts into } \\
\text { invasive phenotype and } \\
\text { influence on the motility of } \\
\text { these cells } \\
\text { 3)prevention of hypoxic induced } \\
\text { apoptosis }\end{array}$ & $\begin{array}{l}\text { Increased decidual expression } \\
\text { and secretion of HB-EGF }\end{array}$ \\
\hline $\begin{array}{l}\text { Matrix } \\
\text { metalloproteinase } \\
\text { s (MMPs) }\end{array}$ & Soluble form & $\begin{array}{l}\text { Involvement in trophoblast } \\
\text { invasion into endometrial } \\
\text { tissues }\end{array}$ & Increased expression \\
\hline $\begin{array}{l}\text { Tissue inhibitors of } \\
\text { metalloproteinase } \\
\text { s (TIMPs) }\end{array}$ & Soluble form & $\begin{array}{l}\text { Inhibition of metalloproteinases } \\
\text { and their function }\end{array}$ & Reduction of expression \\
\hline $\begin{array}{l}\text { Macrophage } \\
\text { antigen } 1 \text { (Mac1) }\end{array}$ & $\begin{array}{l}\text { Surface of myeloid } \\
\text { cells }\end{array}$ & $\begin{array}{l}\text { Coordination of adhesive } \\
\text { functions of leukocyte and their } \\
\text { migration }\end{array}$ & $\begin{array}{l}\text { Interference with myeloid cell } \\
\text { adhesion and transmigration }\end{array}$ \\
\hline $\begin{array}{l}\text { Platelet/endothelia } \\
\text { I cell adhesion } \\
\text { molecule } \quad 1 \\
\text { (PECAM1) }\end{array}$ & $\begin{array}{l}\text { Surface of platelets, } \\
\text { endothelia, } \\
\text { monocytes, } \\
\text { neutrophils, T-cell } \\
\text { subsets and } \\
\text { granulocyte/macroph } \\
\text { age precursors }\end{array}$ & $\begin{array}{l}\text { transmigration of inflammatory } \\
\text { cells through the endothelial } \\
\text { wall }\end{array}$ & $\begin{array}{l}\text { Interference with inflammatory } \\
\text { cells transmigration }\end{array}$ \\
\hline
\end{tabular}


PeerJ Reviewing Manuscript 


\section{Figure 1}

Figure 1

Antithrombin III after conformational change induced by heparin binding. Reproduced with permission from Whisstoch JC, Pike RN, Jin L, Skinner R, et al. J Mol Biol. 2000; 301:128

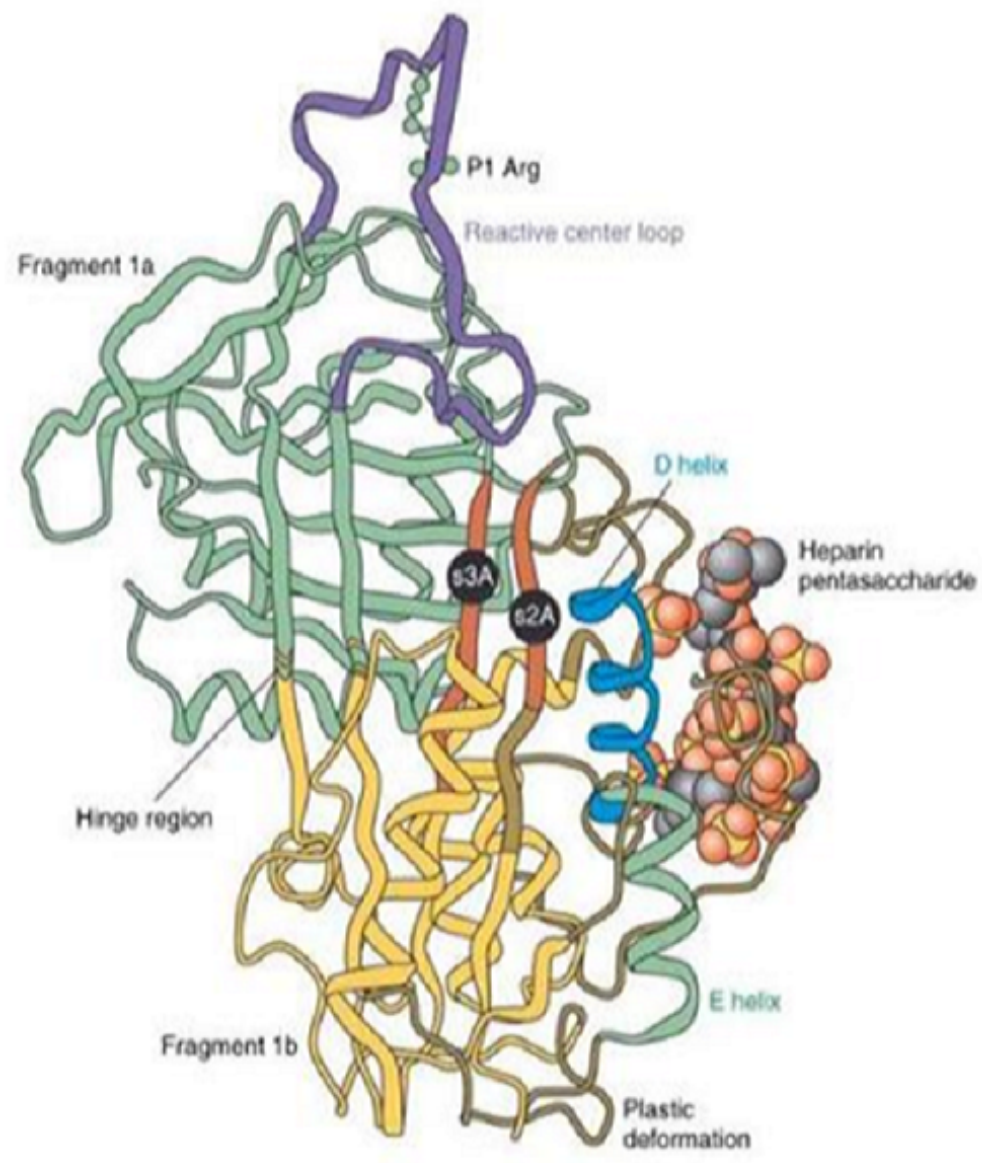


Figure 2

Figure 2

Fig. 2. Mechanisms of interaction between heparin, antithrombin III, thrombin (A) and factor Xa (B).
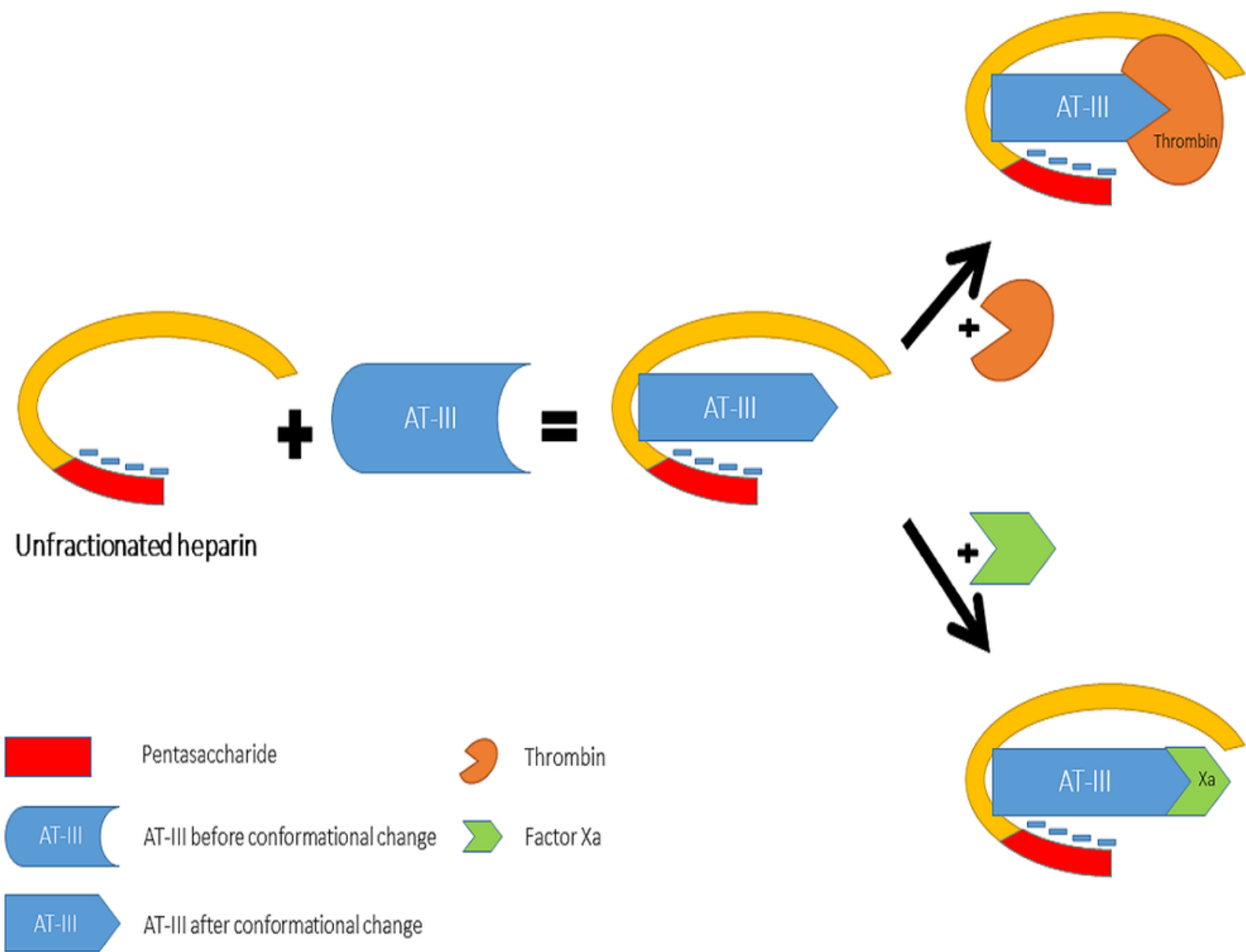

A

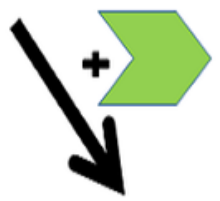

$A I-1 I I$
$0=0$

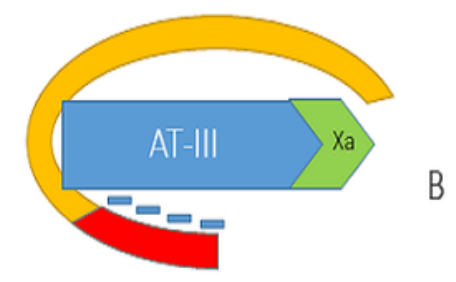

